\title{
Relationship between personality characteristics and stress with internet addiction and marital satisfaction in married women
}

\author{
Mohammad Oraki ${ }^{1}$, Anousheh Fard Aghayi ${ }^{2}$ \\ 1-Associative Professor, Payame Noor University, Tehran, Iran. ORCID: 0000-0002-2869-9146 \\ 2-PHD student of psychology of health, Payame Noor University Dubai International Center, United Arab Emirates \\ (Corresponding Author). ORCID: 0000-0002-3016-6525 \\ E-mail: Anousheh375@gmail.com
}

Received: 27/04/2019

Accepted: 13/07/2019

\begin{abstract}
Introduction: One of the determinants of family health is marital satisfaction, which spouses experience in marriage.

Aim: The purpose of this study was to investigate the relationship between personality traits and stress with Internet addiction and marital satisfaction in married women.

Method: The research design was correlational. The statistical population of the study included all married women referred to health centers in district 6 of Tehran, who responded to the Neo personality questionnaire, Enrique marital satisfaction, Young's Internet addiction, and Perceived Stress Scale. Pearson correlation and regression analysis were used to analyze the findings.

Results: Regression analysis showed that there was a significant positive correlation between personality characteristics of extraversion, conscientiousness, compatibility, and openness with marital satisfaction and there was a significant negative correlation between personality trait psychosis and stress level with marital satisfaction. Also, there is a significant positive correlation between personality traits of psychosis and stress with internet addiction, and there is a significant negative relationship between extraversion, conscientiousness, compatibility and openness with Internet addiction.
\end{abstract}

Conclusion: There is a significant relationship between personality traits and stress with internet addiction and marital satisfaction.

Keywords: Personality characteristics, Stress, Internet addiction, Marital satisfaction

How to cite this article : Oraki M, Fardaghayi A. Relationship between personality characteristics and stress with internet addiction and marital satisfaction in married women. Shenakht Journal of Psychology and Psychiatry. 2019; 6 (4): 13-25 .URL: http://shenakht.muk.ac.ir/article-1747-fa.pdf

Copyright ( 92018 the Author (s). Published by Kurdistan University of Medical Sciences. This is an open access article distributed under the terms of the Creative Commons Attribution-Non Commercial License 4.0 (CCBY-NC), where it is permissible to download, share, remix, transform, and buildup the work provided it is properly cited. The work cannot be used commercially without permission from the journal. 


\title{
بررسى رابطه بين ويزگىهاى شخصيتى و ميزان استرس با اعتياد به اينترنت و رضايت زناشويى در زنان متأهل
}

\begin{abstract}
محمد اوركى'، انوشه فردآقايع
ا. ا.دانشيار، كروه روانشناسى، دانشكاه بِيام نور، تهران، ايران.

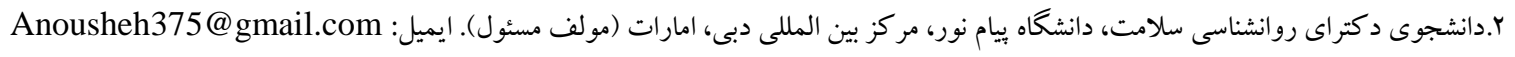

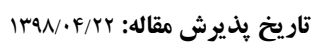

تاريخ دريافت مقاله: •

جكيده

مقدمه: يكى از عوامل تعيين كننده سلامت خانواده رضايت زناشويى است، كه همسر ان در ازدواج تجربه مى كنند.

هدف: هدف يُوهش حاضر، بررسى رابطه بين ويزگى هاى شخصيتى و ميزان استرس با اعتياد به اينترنت و رضايت زناشويى در زنان

متأهل بود.

روش: طرح بثوهش از نوع همبستخى بود. جامعه آمارى يزوهش، شامل كليه زنان متأهل مر اجعه كننده به خانههاى سلامت منطقه 9

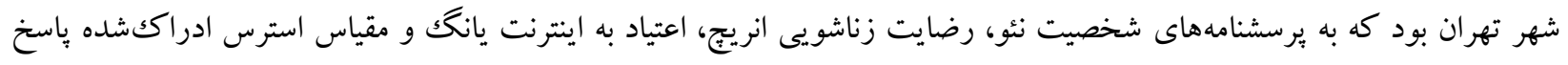
دادند. جهت تحليل يافتها از روش هاى همبستخى بيرسون و تحليل رگر سيون استفاده شد.

يافتهها: نتايج تحليل رگرسيون نشان داد كه بين ويز گىهاى شخصيتى برون گرايى، وظيفهشناسى، ساز گارى و گشودگى با رضايت

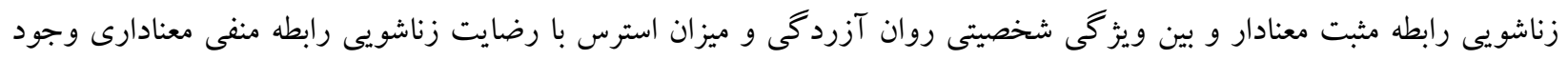

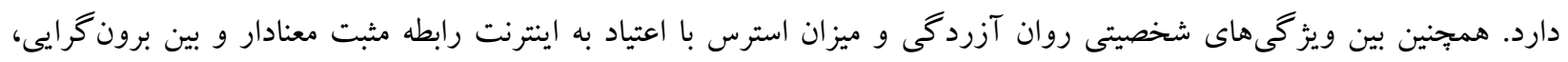

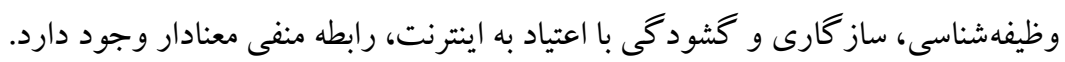
نتيجه كيرى: در مجموع بين ويزگى هاى شخصيتى و ميزان استرس با اعتياد به اينترنت و رضايت زناشويى رابطه معنادارى برقرار است. كليدوازهها: ويز گیىهاى شخصيتى، استرس، اعتياد به اينترنت، رضايت زناشويى 
افسردگى است. برون گرايى به ويز گیىهايى هم:جون

مقدمه

تمايل به شركت در اجتماعات، جرأت طلبى و بر انرزى بـى بكرئ

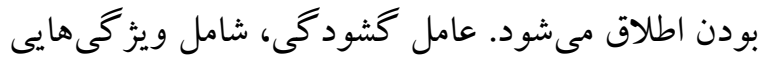
همجيون كنجكاوى، عشق به هنر، انعطاف بذيرى، و و

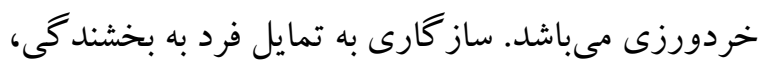

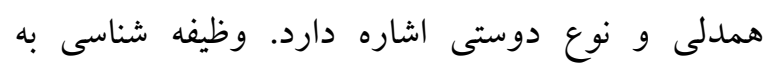
ويز كىهايى هميجون كارا بودن، منطقى بودن و منظم

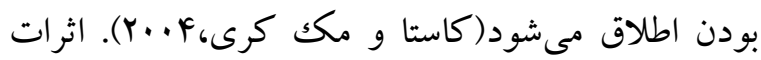
ويز گیىهاى شخصيتى بر عملكرد فردى در حوزه روابط زناشويى توسط برخى از مطالعات مورد توجه قرار كرفته

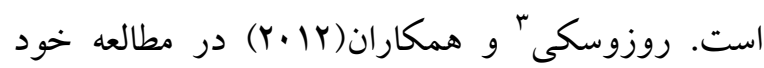
نشان دادند رضايت زناشويى با برون گر ايى بالا در زنان و مسئوليتيذيرى هايين همسران آنان، مرتبط است.

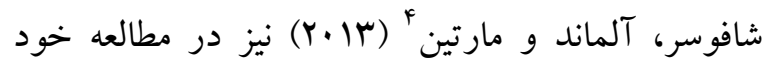
دريافتند زوجينى كه نمره آنان در ويزگى توافق جويى و

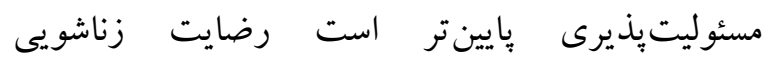
ضعيفترى را گزارش كردهاند. يافتهاى مطالعه فيشر و ورئ

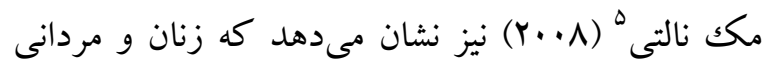

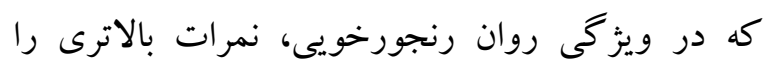

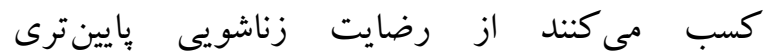
برخوردارند. شاكريان، فاطمى و فرهاديان( •وسا) نيز در يثوهشى نشان دادند كه بين عامل شخصيتى روان آزرده خويى و رضايتمندى زناشويى، رابطه منفى وجود دارد و بين عوامل شخصيتى برون گرايى، وظيفهشناسى، مقبوليت و گثود گى با رضايت زناشويى، رابطه مثبت وجود دارد. يكى از عوامل ديخرى كه رضايت زناشويى را تحت تأثير قرار مىدهد، استرس است. استرس به وسيله ادراكات ذهنى شخص و تفسير وى از موقعيتى كه خارج از

3. Rosowsky

4. Schaffhouser, Allemand,. \& Martin

5 . Fisher \& Mcnulty

2. Costa \& Mccorae. 
وابسته شد، فرصت تعامل با ديخران را از دست مىدهد و زمينه براى بروز عوارض و آسيبهاى اجتماعى و

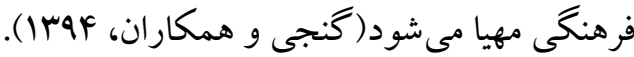
اعتياد به اينترنت، سازهاى گسترده است كه شامل بازى اينترنتى و ساير اشكال استفاده اعتيادى از اينترنت (مثل دانلود اعتيادى، استفاده افراطى از سايتهاى مربوط به شبكههاى اجتماعى و خريد آنلاين اعتيادى) مىشود.

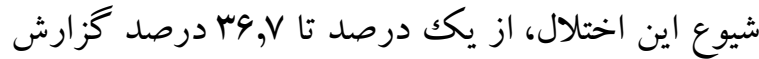

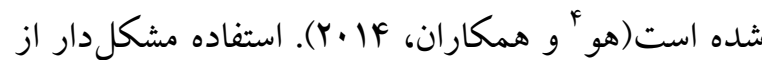
اينترنت، به دو شكل خودش را نشان مىدهد: شكل نخست مربوط به وجوه استفاده از اينترنت است كه به عنوان استفاده بيش از حد يا وسواسى از اينترنت همراه با اشتغال ذهنى و از دست دادن كنترل است؛ و شكل دوم به بيامدهاى منفى و متعدد كذراندن وقت بسيار زياد براى اينترنت اشاره دارد كه منجر به غفلت از فعاليتهاى اجتماعى، ارتباطات، سلامتى و وظايف شغلى و تحصيلى

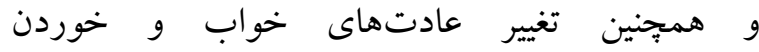

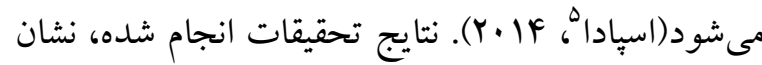
دهنده اين است كه ويز گى هاى شخصيتى تأثير مهمى بر

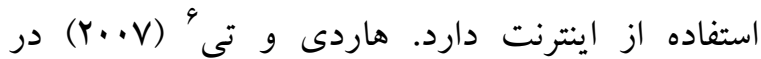
يُزوهشى در اين رابطه نشان داد كه ارتباط مثبت و معنىدارى ميان روان رنجورخويى و اعتياد به اينترنت و رابطه منفى ميان برونگرايى و اعتياد به اينترنت وجود دارد. از طرفى، يافتهاى حاصل از يثزوهشهاى مربوط به رابطه ميزان استرس با اعتياد به اينترنت حائز اهميت است.

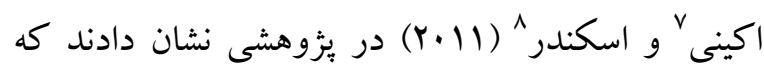
اضطراب ييشبينى كننده معنادار اعتياد به اينترنت است.

\footnotetext{
${ }^{4}$. Ho

5 . Spada

6 . Hardi \& Tee

7. Akini

${ }^{8}$. Iskender
}

توانايىهايش است و مىتواند باعث اختلال در سلامتى وى شود، تعريف مى گردد. بهطوركلى استرس توسط همه افراد تجربه مىشود و بايد توجه نمود كه درجاتى از استرس مى تواند در افزايش و بهبود عملكرد افراد مؤثر باشد. شواهد نشان مىدهد كه اغلب موفقيتهاى انسان در شرايط يراسترس ايجاد مىشود، اما درجات بالاى استرس، عواقب متعددى دارد كه از آن جمله مىتوان به بيمارىهاى جسمى، روانى، اختلالات خواب اشاره كرد(تقوى و همكاران، وش11). رييوكارى' و همكاران نيز در يزوهشى نشان دادند كه زوجهايى كه (Y.V) تحتفشار روانى و استرس قرار دارند، رضايت زناشويى

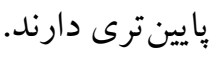

استرس در محيط خانواده مىتواند مشكلات بسيارى ايجاد كند. از اين رو در دهلهاى اخير بيزوهشهاى استرس، خصوصاً در حوزه زوجين توجه بسيارى از يثزوهشخران را به خود جلب كرده و نشان داده شده كه اين مفهوم، نقشى اساسى در كيفيت و ثبات روابط صميمانه زوجين دارد. شواهد نشان مىدهد كه استرس له عامل تهديدكننده رضايت زناشويى و دوران زندگى

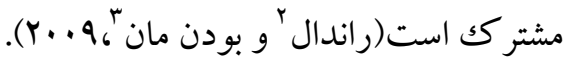
در گذشته، نهاد خانواده تنها كار گزار جامعهيذيرى افراد محسوب مىشد، اما با رشد فناورى، شاهد بيدايش رقباى جديد در كنار خانواده، نظير رسانهاى ارتباطجمعى و فناورىهاى ارتباطى نوين از جمله اينترنت و ماهواره هستيم كه در امر جامعهيذير كردن افراد سهيم هستند. اين

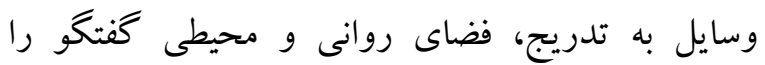


واكرايى سوق مى هنند. وقتى فردى به اينترنت و ماهواره

\footnotetext{
. Repokari

. Rundall

. Boudenman
} 
سال 1919 ساختند. اين برسشنامه شامل •9 سئوال است كه بر اساس تحليل عاملى نمرات NEO-PI تهيه شده است. اين آزمون ينج مورد از ويز گيهاى شخصيتى افراد را موردسنجش قرار مىدهد كه اين ويز گیىها عبارتند از:

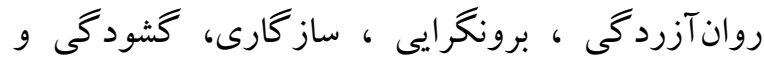
وظيفهشناسى. اعتبار اين برسشنامه با استفاده از روش آزمون-آزمون مجدد در مورد ^•r نفر از دانشجويان به

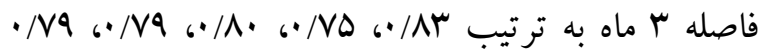
براى عوامل N, E, O, A, C به دست آمده است(گروسى، IrV9). ضريب بايايى اين برسشنامه در يُزوهش حاضر با استفاده از روش همسانى درونى محاسبه شد كه ضريب آلفاى كرونباخ كلى آن برابر |N/ • بود. مقياس رضايت زناشويع انريجّ" اين مقياس توسط فاورز

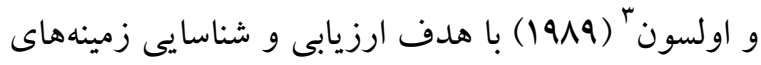
بالقوه مشكلزا و زمينهاى قوت روابط زناشويى تدوين شده است. فرم كو تاه آن شامل FV ماده و از r Y خرده مقياس تشكيل شده است. نمرهخذارى سئوالها از نوع مقياس ليكرت است كه ياسخ سئو الها در يكك طيف ينج

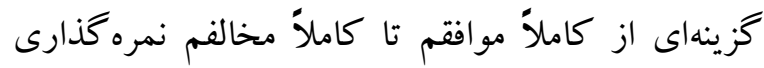
مىشود. نمره بالا بيانگر رضايتمندى بيشتر است. اعتبار كلى اين مقياس را با استفاده از روش ضريب آلفاى كرونباخ بو/ • گز ارش شده است. ضريب آلفاى كرونباخ در يزوهش حاضر 94/• به دست آمد كه حاكى از اعتبار قابل قبول آن مىباشد.

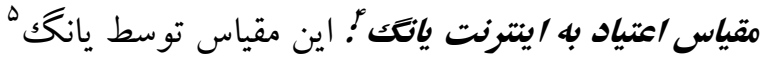

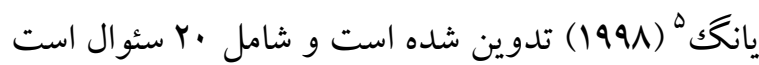
است كه باسخگ

2 . ENRICH Marital Satisfaction Scale

3 . Fawers \& Olson

${ }^{4}$. Internet Addiction Test

5. Young

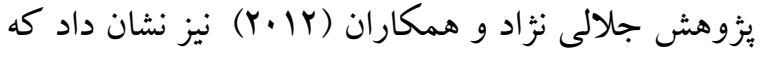
اضطراب و فشار روانى بيشبينى كننده معنادار اعتياد به اينترنت است. بنابر اين با توجه به اهميت متغيرهاى ويزّكى شخصيتى و استرس در ميزان اعتياد به اينترنت و رضايت زناشويى در يُوهش حاضر به بررسى رابطه بين ويز گى هاى شخصيتى و ميزان استرس با اعتياد به اينترنت و رضايت زناشويى در زنان متأهل برداخته شد. نوع مطالعه اين يزوهش از نوع طرح تحقيق توصيفى همبستكى است. جامعه آمارى كليه زنان متأهل مراجعه كننده به خانههاى سلامت منطقه 9 تهران در سال IM I I بود. براى تعيين حجم نمونه از طريق فرمول كر امر به ازاى

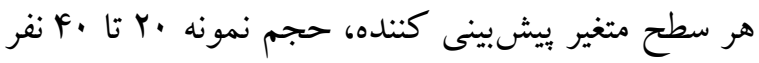
انتخاب شد و جمعاً · إ نفر بر آورد شد. نمونه گيرى در مرحله اول به صورت تصادفى خوشهاى انجام شد. بدين صورت كه ابتدا از بين خانهاى سلامت منطقه 9 تعداد • خانه به صورت تصادفى انتخاب و سبيس از بين آنها . نفر انتخاب شدند. شرايط ورود به مطالعه شامل داشـتن سـابقه حسداقل يكك سال زنـدكى مشـترك، نداشـتن سـا بقه طلاق و مشكلات روانشناختى، داشتن حداقل تحصيلات سيكل و تمايل براى شركت در يثزوهش بـود. معيارهـاى خروج از مطالعه شامل عدم همكارى در تكميل كردن :برسشنامها و و بركردن يرسشنامه بـه صسورت نـاقص بودند.

ابزار مقياس بنج عاملح شخصيت نئو' (NEO-PI) فرم كوتاه:

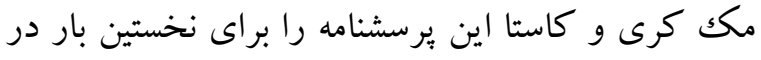

\footnotetext{
${ }^{1}$. NEO Personality Inventory
} 
ويزگ گهاى جمعيت شناختى گروه نمونه، از روش آمار توصيفى شامل جداول فراوانى، ميانكين و انحراف

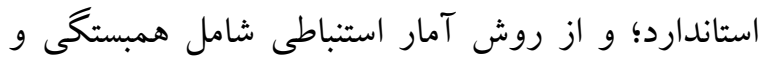
ركرسيون استفاده شد. براى تجزيه و تحليل نتايج به دست آنس آمده نيز، از نرمافزار SPSS استفاده كرديد.

يافتهها

براساس اطلاعات جمعيت شناختى دامنه سنى شركت

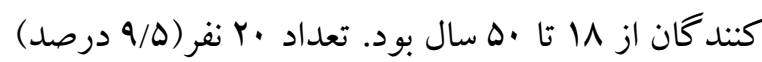

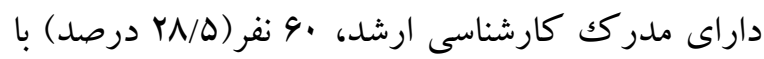

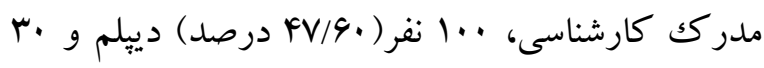

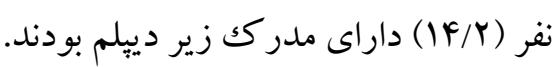
يافتهاى توصيفى شامل ميانكين، انحراف معيار، حداقل ديل

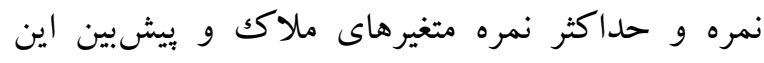
يُزوهش در كل آزمودنىها در جدول ا ارائه شده است.
درجهاى ياسخ دهند. شامل سه بخش اعتياد به ايترنت، در معرض اعتياد به اينترنت و عدم اعتياد به اينترنت مى باشد. دامنه نمرههاى اين آزمون از صفر تا ... است، نمره

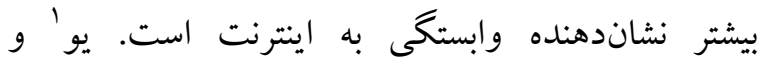

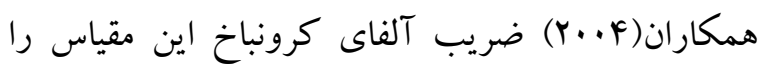

$$
\text { بيش از 9 • به دست آوردند. }
$$

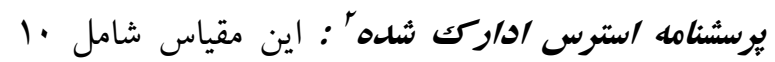
سئوال است كه به منظور ارزيابى ميزان استرس و فشار روانى تجربه شده توسط فرد، بهوسيله كوهن، كامارك و و

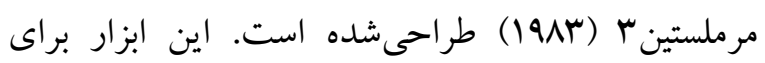
تعيين ميـزان شــناخت افـراد از اسـترس خــود در مقابـل رويــدادهاى غيرقابل ييشيبينى و غيرقابل كنترل

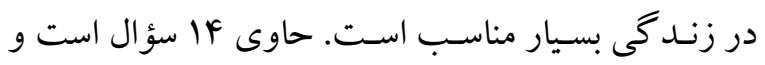

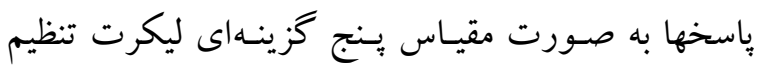

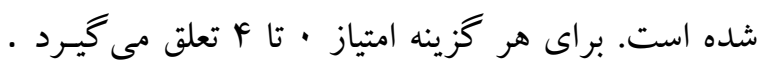

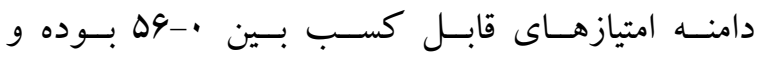

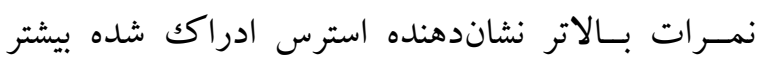
است. اين مقياس داراى تعدادى سئوال مستقيم نيز در

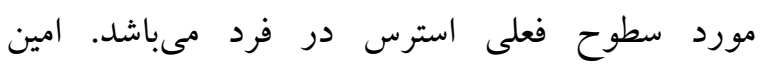

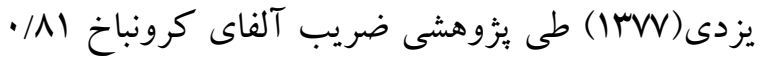
را براى اين مقياس گزارش نموده است.

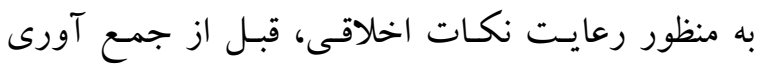

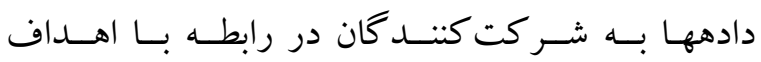

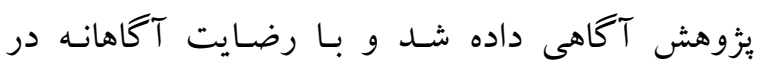

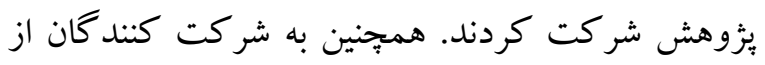

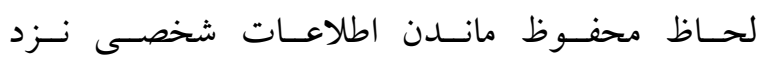

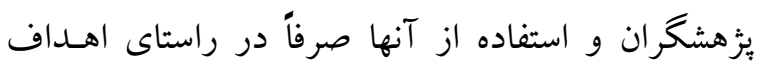

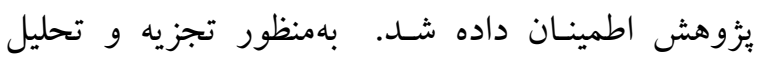

1. Yoo

${ }^{2}$. Perceived Stress Questionnaire

3 . Cohen, Kamarck \& Mermelstein 


\begin{tabular}{|c|c|c|c|c|}
\hline انحر اف استاندارد & ميانغين & حداقل نمره & حداقل نمره & متغير ها \\
\hline$\Delta / \cdot Y$ & $r F / \Delta r$ & rᄉ & $r$ & روان رنجورخويى \\
\hline$\Delta / / Y$ & $|N / r|$ & rq & f & برون كرايى \\
\hline 9111 & TI/TD & rr & r & ساز گارى \\
\hline$F / .9$ & $19 / 99$ & f. & 9 & تشودگى \\
\hline$\Delta / F \Delta$ & $|F /| Y$ & $\Delta 1$ & 1 & وظيفهشناسى \\
\hline$N / r)$ & I9/Ar & 94 & $r$ & ميزان استرس \\
\hline$|r /| \mid$ & $F \cdot / q V$ & sT/VA & F & اعتياد به اينترنت \\
\hline $9 / \Delta r$ & $99 / \Gamma F$ & Irr & 99 & رضايت زناشويى \\
\hline
\end{tabular}

ضرايب همبستكى بيرسون بين ويز گىهاى شخصيتى و ميزان استرس با رضايت زناشويى در جدول ب بيان شده است.

\begin{tabular}{|c|c|c|}
\hline سطح معنىدارى & رضايت زناشويى & متغير ها \\
\hline$\cdot / \cdot 1$ & $-\cdot / r \cdot 1$ & روان رنجور خويى \\
\hline$\cdot / \cdot 1$ & $\cdot / 4 \Delta q$ & برون كرايى \\
\hline.$/ .1$ & • TrQ & سازعارى \\
\hline 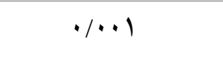 &.$/ 490$ & عشودگى \\
\hline.$/ \cdot 1$ &.$/ 491$ & وظيفهشناسى \\
\hline$\%$ & $-\cdot \mid A Y I$ & ميزان استرس ادراكتشده \\
\hline
\end{tabular}

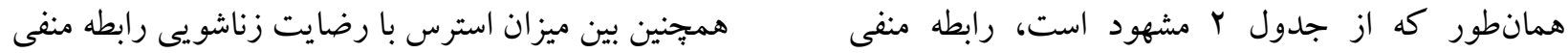

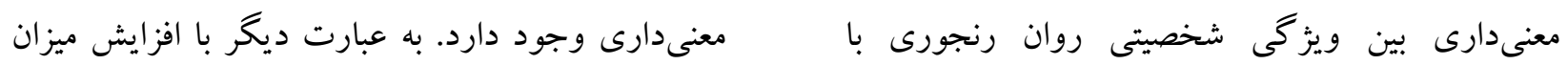
رضايت زناشويى وجود دارد و بين ويز گىهاى شخصيتى استرس، رضايت زناشويى كاهش مى يابد. نتايج تبيين

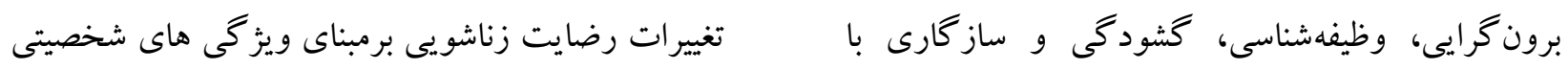
رضايت زناشويى رابطه مثبت معنىدارى وجود دارد. و ميزان استرس در جدول ب نشان داده شده است.

\begin{tabular}{|c|c|c|c|c|c|c|}
\hline معنىدارى & Fقدار Fق & ضريب تعيين ) & $\begin{array}{c}\text { ضريتغى } \\
\text { همبتى } \\
\text { (R) }\end{array}$ & درجه & مجذوراتين & شاخص \\
\hline \multirow[t]{2}{*}{.$/ . \cdot 1$} & $19 / \%$. & $\cdot / 49$ & $\cdot / 01$ & $\Delta$ & $\Lambda \Delta \Delta \Delta / \Gamma F$ & ركرسيون \\
\hline & & & & riq & FFT/YN & باقيمانده \\
\hline
\end{tabular}


رضايت زناشويى را تبيين مىكند. برآورد ضرايب

نتايج جدول r نشان مىدهد كه مدل كلى ركرسيون با

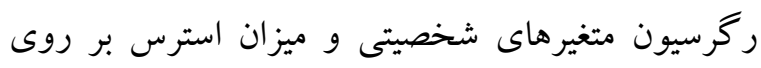

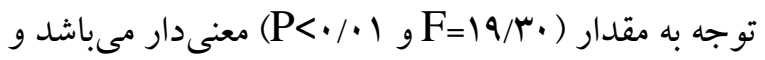
رضايت زناشويى در جدول f ملاحظه مى شود.

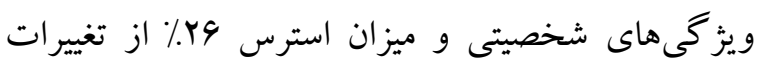

\begin{tabular}{|c|c|c|c|}
\hline سطح معنىدارى & ضده ضب استاندارد & 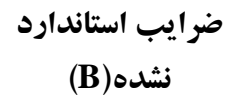 & متغير هاى بيشبين \\
\hline.$/ \cdot 1$ & - & $|F| / F$. & مقدار ثابت \\
\hline$\cdot / \cdot 1$ & ./FYG & $\cdot /$ NA9 & برون كرايـ \\
\hline$\cdot / \cdot .1$ & $-\cdot /$ /NI & - NYY & روان آزرده خويى \\
\hline$\cdot / \cdot 1$ & $\cdot / r \Delta \Delta$ & $\cdot / 4 \wedge 9$ & وظيفهشناسى \\
\hline$\% \cdot \cdot 1$ & . TKY &.$/ 091$ & تشودىى \\
\hline.$/ .1$ & ./ITr &.$/ 194$ & ساز كارى \\
\hline.$\cdot \cdot 1$ & •/ MAQ & $-\cdot /$ ATT & ميزان استرس اداركى شده \\
\hline
\end{tabular}

شخصيتى و ميزان استرس با رضايت زناشويى رابطه

با توجه به ضرايب استاندارد در جدول ^ مىتوان كفت

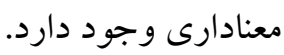

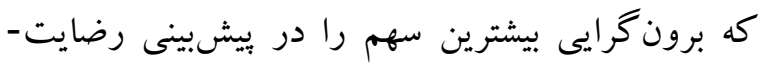

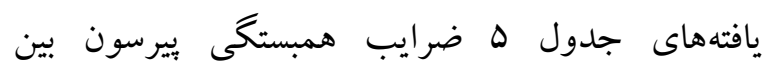
مندى زناشويى ايفا مى كند و پِ از آن ميز آنس استرس، ويزگىهاى شخصيتى و ميزان استرس را با اعتياد به روان آزرده خويى، وظيفهشناس، گشودگى و ساز كارى

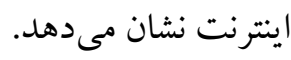

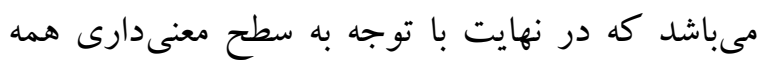
ضرايب در مدل مىتوان كفت كه بين خصوصيات

\section{جدوله همبستكى بيرسون بين ويزٔكىهاى شخصيتى و ميزان استرس با اعتياد به ايتترنت}

\begin{tabular}{|c|c|c|}
\hline سطح معنىدارى & اعتياد به اينترنت & متغير ها \\
\hline.$/ \cdot 1$ & •/ra9 & روان رنجور خويى \\
\hline.$/ \cdot 1$ & $-\cdot /$ MFF & برون كرايـ \\
\hline.$/ \cdot 1$ & $-\cdot / 490$ & ساز كارى \\
\hline.$/ \cdot 1$ & $-\cdot / \mu r$. & كشودمى \\
\hline.$/ \cdot 1$ & $-\cdot /$ HYA & وظيفهشناسى \\
\hline.$\cdots 1$ & . / FFY & ميزان استرس ادراككشده \\
\hline
\end{tabular}

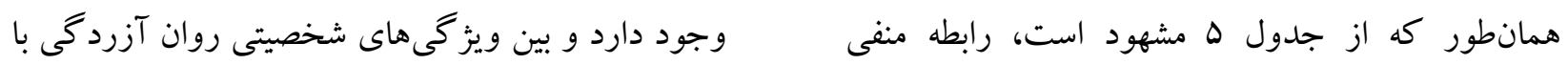
معنى ساز كارى، كشودگى، وظيفه وناسى با اعتياد به اينترنت 


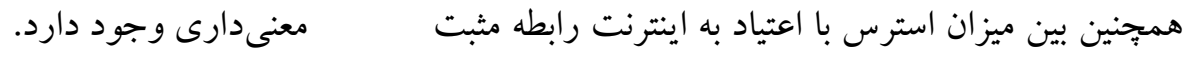

\begin{tabular}{|c|c|c|c|c|c|c|}
\hline معنى دارى & Fقدار F & $\begin{array}{c}\text { ضريب تعيين } \\
\left(\mathbf{R}^{2}\right)\end{array}$ & ضريبتى & آزادى درجه & مجانكين & شاخص \\
\hline
\end{tabular}

(R)

\begin{tabular}{|c|c|c|c|c|c|c|}
\hline.$\cdots 1$ & $q \cdot / \cdot V$ & .199 & $\cdot / \Lambda \mu$ & $\Delta$ & $19909 / 91$ & ركرسيون \\
\hline & & & & $19 V$ & $|\wedge F / 9|$ & باقيمانده \\
\hline
\end{tabular}

يافته هاى جدول V نشان مىدهد كه ويز خى هاى شخصيتى و ميزان استرس، توانايى بيشبينى تغييرات اعتياد به

اينترنت را به طور معنادارى دارند.
همان گونه كه در جدول 9 نشان داده شده است، مدل كلى رگرسيون معنى و ويثز گیى هاى شخصيتى و ميزان استرس 99٪ از تغييرات اعتياد به اينترنت را تبيين مى كند.

\begin{tabular}{|c|c|c|c|}
\hline سطح معنى دارى & ضده(ايب استاندارد & 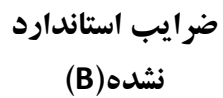 & متغيرهاى بيشبين \\
\hline$\% / \cdot 1$ & - & FA/YK & مقدار ثابت \\
\hline.$/ \cdot 1$ & - /FYG &.$/ 994$ & روان آزرده خويى \\
\hline.$\cdot \cdot 1$ &.$- / 490$ & $-\cdot$ VIr & وظيفهشناسى \\
\hline$\% \cdot \cdot 1$ & $-\cdot /$ raf & $-\cdot 1091$ & برون كرايى \\
\hline$\% \cdot \cdot 1$ & $-\cdot / Y F I$ & 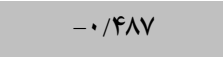 & تشود \\
\hline$\cdot / \cdot 1$ & $-\cdot / I r T$ & $-\cdot / 194$ & ساز كارى \\
\hline$\% \cdot \cdot 1$ & $\cdot / 499$ & $\cdot / 491$ & ميزان استرس ادار كك شده \\
\hline
\end{tabular}

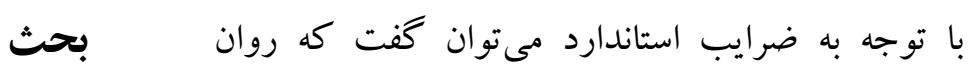
يافتهاى بزّوهش و ادبيات بثزوهش نشان دهنده همخوانى نتايج حاصل از اين بزوهش با نتايج تحقيقات قبلى است. آزردهخويى، بيشترين سهم را در بيشبينى رضايتمندى

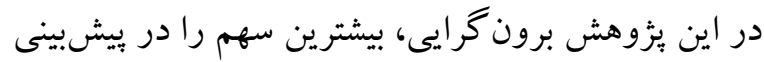
زناشويى ايفا مى كند و وِ بس از آن ميزان استرس، رضايتمندى زناشويى به عهده دارد كه همخوان با يافته

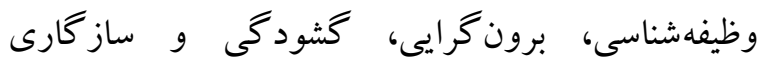

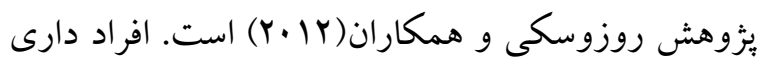
مىباشد كه در نهايت با توجه به سطح معنىدارى همه ضرايب در مدل مىتوان كفت كه بين خصوصيات نمره بالا در اين عامل، معمولاً تمايل به اجتماعى بودن، احساسى بودن و صميمى بودن داشته و با افراد متفاوت شخصيتى و ميزان استرس با اعتياد به اينترنت رابطه

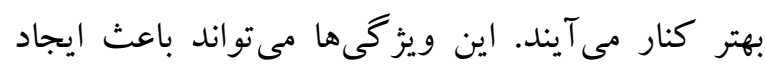


هدف ديخر يزوهش بررسى رابطه ويز گیىهاى شخصيتى

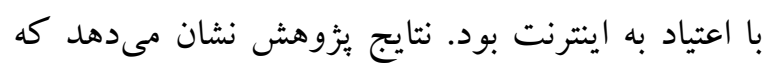

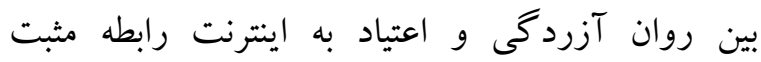

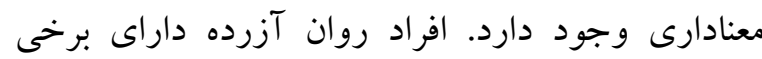
ويثز گیىاى متمايز كننده هستند كه عبارتند از ترس، غم،

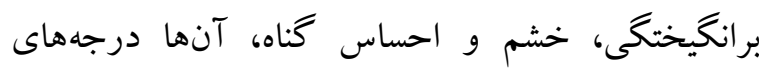
انطباق ضعيفترى با ديخران دارند و از نظر عاطفى

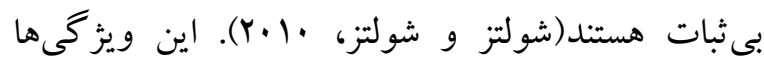
مىتواند موجب شود كه افراد روان آزرده، توانايى كمترى براى مقابله با جالشهاى زندگى روزمره داشته باشند و براى تسكين استرس و فشار روانى به فضاى لرى

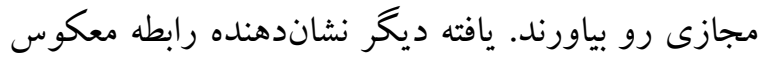
معنىدار بين برونگرايى با اعتياد به اينترنت بود. افراد برون گرا اشخاصى اجتماعى، دوست دار مردم، علاقهمند به شركت در اجتماعات و اهل كفتو گو هستند(يروين، (Y...

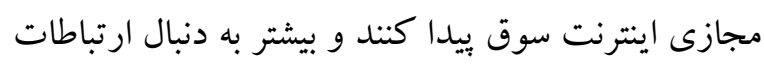
واقعى باشند. يافته ديخر يثزوهش نشاندهنده رابطه منفى انسى

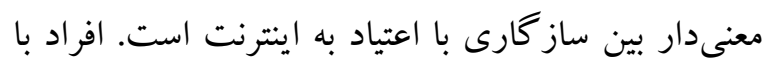

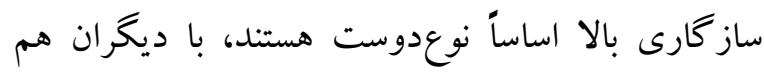

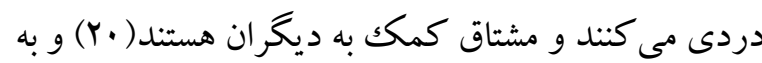
دليل دارا بودن همين خصايص، كمتر احتمال دارد كه براى كنار آمدن با جالشهاى زندگى به دنياى غيرواقعى

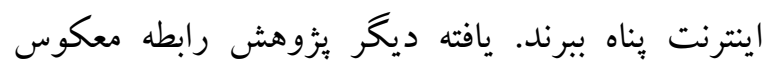
معنىدار بين وظيفهشناسى و اعتياد به اينترنت را نشان

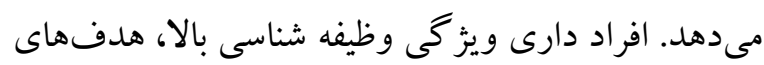
معينى در دنياى واقعى براى خود در نظر مى گيرند و به اصول اخلاقى يايبندى بالايى دارند. در مقابل افراد داراى

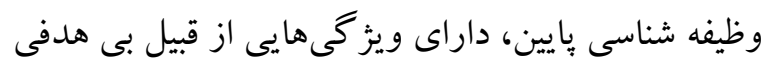

روابط زناشويى محكم بين زن و مرد شود و افزايش ميزان رضايت زناشويى را به دنبال داشته باشد. يافته ديخر يثزوهش نشان مىدهد كه روان آزرده خويى با رضايت

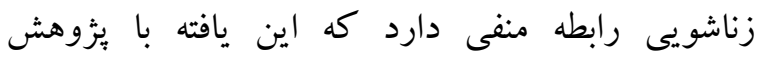
شاكريان، فاطمى و فرهاديان(·وسا) همسو مىباشد. در واقع روان آزرده خويى بيشبينى كننده قوى رضايت زناشويى يايين است. به طورى كه نمره بالا در اين عامل، نشان دهنده سطح ساز گارى يايين فرد است و عدم ثبات عاطفى را در روابط بين فردى نشان مىدهد و در نهايت جنين ويز كىهايى احتمال جدايى و طلاق را افزايش مىدهند. در اين بثزوهش بين وظيفهشناسى و رضايت زناشويى رابطه مثبت معنىدارى به دست آمد. افراد دارى اين خصيصه نياز به بيشرفت دارند و به همين خاطر براى نخهارى رابطه موفق خود دست به تلاش مىزنند. اين

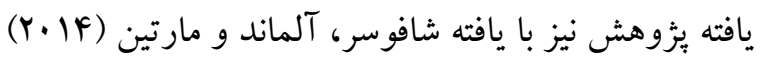

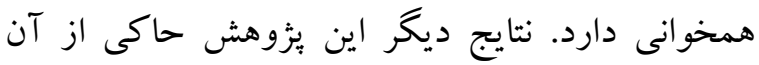
است كه بين سازگارى و رضايت زناشويى رابطه معنى دارى وجود دارد. افراد با اين خصوصيت شخصيتى، در بيى ايجاد ساز گارى و راحت كنار آمدن با افراد هستند

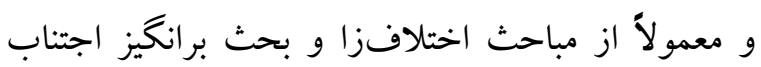
مىورزند. در اين يزوهش، گشود گیى نيز سهم معنىدارى در بيشبينى رضايت زناشويى را داشت. اين ويز كى شخصيتى با علاقه به ايدها و درك احساسات ديخران همراه است و مىتواند باعث افزايش رغبت در توجه به صحبتها و خواستهاى همسر و فهم و و درك ديد كاههاى او باشد. اين يافتهاى بثزوهش نيز با يافته هاى يثزوهش شاكريان، فاطمى و فرهاديان( •وسا) همخوانى دارد. 
نتيجه عوارض اعتياد به اينترنت باشد؛ به طورى كه افراد

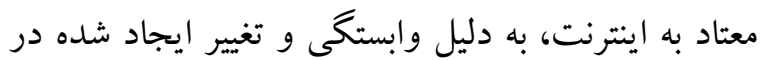
سبك زندگى آنها، مستعد اختلالات روانى شوند و

$$
\text { دجار استرس و اضطراب كردند. }
$$

\section{نتيجه كيرى}

به طور كلى، نتايج اين مطالعه، نشاندهنده ارتباط معنادار بين ويز گىهاى شخصيتى و ميزان استرس با اعتياد به اينترنت و رضايت زناشويى در زنان متأهل بود. اهميت عوامل و صفات شخصيتى و استرس در رضايتمندى زناشويى بيانكر آن است كه خصوصيات شخصيتى بيش بينى كنندههاى معنى دار از رضايت زناشويى مىباشند كه اين امر مىتواند افراد را در انتخاب همسر براساس ويز گيهاى شخصيتى طرفين كمك نمايد. نتيجه ديخر عاطضه ى استرس و اعتياد به اينترنت از محدوديتهاى اين يثزوش مىتوان به محدوديت در كروه سنى و و جنسيتى اشاره كرد و بيشنهاد مىشود ئزوهش هاى آتى بـى در گروههاى سنى و جنسيتى متفاوتى صورت گيرد.

\section{سياسگزارى}

از مسئولين محترم خانه هاى سلامت منظقه 9 تهران و تمامى افرادى كه در مطالعه حاضر شركت داشتند، تقدير

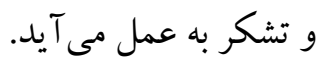

\section{References}

Akin A, \& Iskender M. (2011). Internet addiction and depression, anxiety and stress. International online joumal of educational sciences, 3(1),138-148.

Amin Yazdi SA. (1998). Investigating the relationship between documentary style and perceived
و فقدان يايبندى به اصول اخلاقى اند. يس طبيعى است كه جنين افرادى با احتمال بيشترى به سمت اعتياد به اينترنت كشيده شوند؛ جون اكر فرد بر خود كنترل لازم را نداشته باشد، اينترنت به راحتى مىتواند او را به سمت خود جذب كند. اين يافتهها با يافتهاى يُووهش هاردى و تى (Y.VV)

همينطور نتايج ئزوهش نشان داد كه بين استرس و رضايت زناشويى رابطه منفى معنىدارى وجود دارد كه

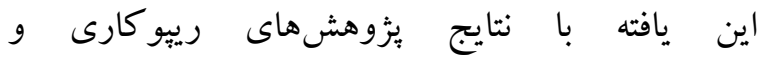

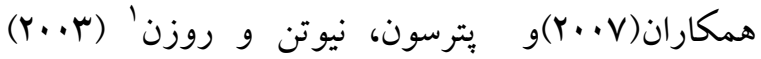
همخوانى دارد. در تبين اين رابطه مىتوان كفت، افرادى لئى كه تحت فشار روانى بيشترى هستند و يا در مقابله با

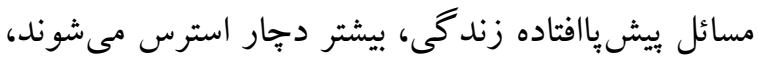
هنگام برخورد با مشكلات و شرايط سخت زندگى نيروى خود را از دست مىدهند، احساس ضعف بيشترى مى كنند، و در نتيجه بهداشت روانى آنها تحت تأثير قرار مى گيرد و نهايتاً از رابطه زناشويى خود احساس رضايت

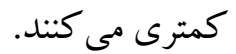
يافته ديخر يزٔوهش مربوط به رابطه ميزان استرس با اعتياد به اينترنت بود كه نتايج، نشاندهنده رابطه مثبت معنادار بين اين دو متغير بود و با نتايج يافتهاى يثزوهشهاى

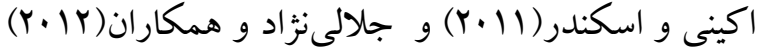
همخوان مىباشد. در تبيين اين يافته مىتوان كفت كه افراد داراى سطح بالاى استرس براى فرار از اين فشار

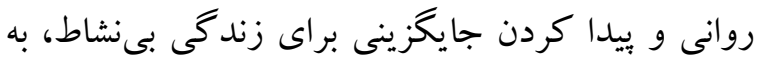
اينترنت و فضاى مجازى بناه مى آورند كه اين شرايط زمينه را براى وابستحى بيشتر آنها به اينترنت مهيا مى كند

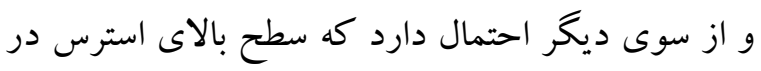

\footnotetext{
${ }^{1}$. Peterson, Newton \& Rosen
} 
stress. Final report of the research project, Ferdowsi University of Mashhad. (in Persian).

Attari Y, Amanollahfard A, \& Mehrabizadeh honarmand M. (2007). The Relationship between Personality Characteristics and Individual-Family Factors with Marital Satisfaction in Employees of Public Offices in Ahwaz. Journal of Educational Sciences and Psychology, 13(2), 81-108 (in Persian).

Cohen S, Kamarck T, \& Mermelstein R. (1983). A Global Measure of Perceived Stress. Joumal of Health and Social Behavior, 24(4), 385396.

Fisher TD, \& Mcnulty JK. (2008). Neuroticism and marital satisfaction: The mediating role played by the sexual relationship. Joumal of family psychology, 22 (1), 96-112.

Fowers BJ, \& Olson DH. (1989). Enrich Marital Inventory: A discriminant validity and cross-validation assessment. Joumal of marital and family therapy, 15(1), 65-79.

Ganji M, Niazi M, \& Malekpourshahraki A. (2014). The study of the effect of addiction to modem communication technologies (Intemet and Satellite) on familial convergence in Shahrekord . Joumal of Social Studies and Research of Iran, 4(1), 167-194 (in Persian).

Garousifarshi M. (2000). New Approach to Personality Evaluation, Application of Factor Analysis in Personality Studies Tabriz:, Jameehpazhooh. (in Persian).

Hardie E, \& Tee MY. (2007). Excessive Internet use: The role of personality, loneliness and social support networks in Internet Addiction. Australian Journal of Emerging Technologies \& Society, 5(1),231-245.

Ho RC, Zhang MW, Tsang TY, Toh AH, Pan F, Lu Y, Cheng C, Yip PS, Lam LT, \& Lai CM. (2014). The association between intemet addiction and psychiatric co-morbidity: a meta-analysis. BMC psychiatry, 14(1), 171183.

Lawrence P. (1989). Psychology of personality. Tehran: Rasa publication,215-240.

Mccrae RR, \& Costa Jr PT. (2004). A contemplated revision of the NEO Five-Factor Inventory.
Personality and individual differences, 36(3), 587-596.

Peterson BD, Newton CR, \& Rosen KH. (2003). Examining conguence between partners' perceived infertility-related stress and its relationship to marital adjustment and depression in infertile couples. Family process, 42(1),59-70.

Randall AK, \& Bodenmann G. (2009). The role of stress on close relationships and marital satisfaction. Clinical psychology review, 29(3), 110-115.

Razieh J, Ghasempour A, Ajdari Z, \& Sadeghigoogari N. (2012). The relationship between Intemet addiction and anxiety in the universities students. Interdisciplinary Joumal of Contemporary Research in Business, 4(2), 942-949 (in Persian).

Repokari L, Punamaki RL, Unkila-Kalio L, Vilska S, Poikkeus P, Sinkkonen J, Almqist F, Tiitinen A, \& Tulpplala M. (2007). Infertility treatment and marital relationships: a 1-year prospective study among successfully treated ART couples and their controls. Human reproduction, 22(5), 1481-1491.

RosowskyE, King KD, CoolidgeFL, Rhoadess CS, \& Segal DL. (2012). Marital satisfaction and personality traits in long-term marriages: An exploratory study. Clinical Gerontologist, 35(2), 77-87.

Schaffhouser K, Allemand M, \& Martin M. (2014). Personality traits and relationship satisfaction in intimate couples: Three perspectives on personality. European Joumal of Personality, 28(2), 120-133.

Schultz SE. (2010). Personality theories, Tehran virayesh.320-335.

Shakerian A, Fatemi A, \& Farhadian M. (2011). The Relationship between Personality Characteristics and Marital Satisfaction. Scientific Joumal of Kurdistan University of Medical Sciences, 16(1), 92-99.

Spada MM. (2014). An overview of problematic Intemet use. Addictive behaviors, 39(1),3-6.

TaghaviLarijani TT, Bard FR, Khatoni A, \& Monjamed Z. (2007). Comparison of 
Stressors among Nursing and Midwifery Students of Tehran University of Medical Sciences. hayat magazine, 13(2), 61.-70 (in Persian).
Young KS. (1998). Internet addiction: The emergence of a new clinical disorder. Cyberpsychology \& behavior, 1(3),237-244. 